P a g e $\mid 1$

\title{
Title: The professionalization of financial planning in Australia: an institutional logics perspective
}

\author{
Daniel W. Richards \\ School of Administrative Studies, York University, Toronto, Canada, and \\ Sarath Lal Ukwatte Jalathge and Prem W. Senarath Yapa \\ School of Accounting, Information Systems and Supply Chain, RMIT University, \\ Melbourne, Australia
}

Purpose - This paper researches the professionalization of financial planning in Australia. We investigate how the institutional logic of major institutions inhibits this occupation from moving toward a professional status.

Design/methodology/approach - The study uses documentary analysis of government inquiries into Australian financial services from 1997 to 2017 to ascertain the various institutional logics relating to the professionalization of financial planning. The method involves generating ideas from the data and applying an institutional logic framework to make sense of impediments to the professionalization of financial planning in Australia.

Findings - The regulator adopted a self-regulation logic that empowered financial institutions to govern financial advice. These financial institutions have a logic of profit maximization that creates conflicts of interest in financial planning. The financial planning professional bodies adopted a logic of attracting and retaining members due to a competitive professional environment. Thus, financial planners have not been defined as fiduciaries, professional standards have not increased, and an ineffective disciplinary resolution system exists.

Research limitations/implications - This research illustrates the various institutional logics that need to be addressed to professionalize financial planning in Australia. However, the data used is limited to that drawn from the parliamentary inquiries.

Originality/value - Prior research on the emergence of professions such as accounting has shown that financial institutions are sites of professionalization. Our research shows that financial institutions impede professionalization in financial planning. Also, where the state granted legitimacy to other professions, our research indicates the state regulator's logic of selfregulation has not legitimized financial planning.

Keywords: Financial Advice, Financial Planning, Sociology of Professions, Professional Bodies, Institutional Logics.

Paper type: Research Paper 


\section{Introduction}

“...history tells the story of an incomplete transformation - from an industry dedicated to the sale of financial products to a profession concerned with the provision of financial advice. I say 'incomplete' because I do not believe that the practice of giving financial advice is yet a profession." (Hayne, 2019, p. 119)

This quote illustrates the current plight of attempts to professionalize financial planning in Australia, which have not yet succeeded despite ongoing regulatory reform (Cull, 2009; McInnes, 2020). However, academic literature investigating the development of professions in related fields, such as accounting (Edwards et al., 2007; Abbott, 1988), highlights the importance of regulation. Other research argues that the state is influential in creating professional jurisdictions in developed (Chua and Poullaos, 1993) and developing economies (Yapa et al., 2016). The relationships between the state and professional bodies in creating the accounting profession are dynamic, reciprocal, and complex (Ballas, 1998; Caramanis, 2002).

There is a dearth of literature on the development of financial planning as a profession from an institutional perspective. Research on this topic does not examine impediments to professionalization (Cull, 2009; Murphy, 2018) but instead focuses on the level of professionalism among financial planners ${ }^{1}$ (Saunders, 2010; Watts and Murphy, 2009). Academic literature on professions focuses on threats to existing professions (Adams, 2017), and accounting literature investigates professionalization in developing countries (Hopper et al., 2017). Neither area of literature contends with threats to occupations in developed counties that are attempting to professionalize. The motivation for this study is to address this gap in the research, and its objective is to gain insights into institutional challenges in professionalizing financial planning in Australia.

The Australian state has intervened in regulating financial advice, yet financial planning has not been professionalized. A typical tale is that a scandal shines a light on the unethical behavior of financial institutions, shows inadequate policing by regulators, and highlights professional bodies struggling to enforce standards (Hayne, 2018; Hayne, 2019). Following this, a raft of legislation is introduced (McInnes, 2020). Despite this recurring scenario, there is virtually no organized financial planning profession in the financial planning industry, at least not in the sense that a critical social observer might expect (Hayne, 2019). Therefore, we

\footnotetext{
${ }^{1}$ We use the term "financial planner" to refer those who provide personal financial advice as defined by the Corporations Act 2001 (Cth), and this can include financial advisers or financial advisors.
} 
contend that institutions operating in financial planning have failed to organize the profession in Australia, and this is a topic worthy of academic research.

We use a framework based on institutional logics (Friedland and Alford, 1991; Greenwood et al., 2011), which evolved from new institutional theory (Dimaggio and Powell, 1983). This framework can locate the institutional logics involved with the professionalization of financial planning. Thus, this paper seeks to address the following research question:

How do institutional logics shape the professionalization of financial planning in Australia?

The study answers this research question by analyzing the documentary evidence provided by the Parliamentary Joint Committee on Corporations and Financial Services ${ }^{2}$ (PJCCFS) inquiries, the Wallis Inquiry, the Financial Systems Inquiry, and the Royal Commission into Misconduct in the Banking, Superannuation and Financial Services Industry (henceforth referred to as the Royal Commission; details of data are in Appendix A). These inquiries received public submissions on contentious issues in the financial services industry from the general public, regulators, professional bodies, and financial institutions.

The main finding is that the three institutions that play a predominant role in controlling financial planning have different institutional logics that inhibit professionalization. Specifically, the regulator, the Australian Securities and Investment Commission (ASIC), held a logic of self-regulation based on market efficiency, causing it to take a minimalist approach to standard-setting and to adopt a licensing regulatory mechanism that empowers the financial institutions. These institutions, which are driven by a logic of profit maximization and used financial planners to sell financial products to customers. The sales orientation of financial planning has instilled conflicts of interest in the occupation, where financial planners serve the institution remunerating them rather than acting in their clients' best interest. The conflicts of interest are exacerbated through vertical integration, where financial institutions have expanded to become both product providers and financial advice institutions. The professional community in financial planning is fractured, with many bodies fighting for membership and professional bodies sharing control over financial planners with other stakeholders. A logic emanating from professional bodies was to attract and retain members. This logic inhibited professional bodies from enforcing the jurisdiction of financial planners as fiduciaries and

\footnotetext{
${ }^{2}$ Before 2001, this was known as the Parliamentary Joint Statutory Committee on Corporations and Securities.
} 
prevented them from setting high professional standards. The inability of these institutions to professionalize financial planning is exemplified by the creation of a new body for this purpose, the Financial Adviser Standards and Ethics Authority (FASEA). FASEA (2019) has raised educational, ethical, and competency standards for financial planners but has yet to address the regulatory mechanism in financial planning.

This research contributes to the wider debate about the influences of professions (Adams, 2017; Evetts, 2013) and accounting professionalization (Veylayutham and Perera, 1996; Mihret et al., 2020). Where research has found that state intervention is essential for legitimizing a profession, our research finds that an institutional logic of self-regulation based on free-market efficiency adopted by a state regulator can impede this professionalization process. Also, where accounting research has found that large financial institutions can be the site of professionalization (Cooper and Robinson, 2006; Hopper et al., 2017), we find that large financial institutions with a profit-making logic can impede the professionalization of financial planning. Finally, a threat to accounting professional bodies is that a fiduciary duty logic is being replaced by a profit maximization logic (Thornton et al., 2005). While accountants have maintained relevance despite scandals (Carnegie and O'Connell, 2014; Toms, 2019), the financial planning professional bodies cannot enforce a fiduciary duty as they have a competing need to attract and maintain members.

The paper is organized as follows: Section 2 reviews the literature, and Section 3 derives a theoretical framework using institutional logics. Section 4 outlines the data and methods, and Section 5 reports our findings. Section 6 discusses, and Section 7 concludes the paper.

\section{Literature review}

\subsection{Professionalization and threats to professions}

Professionalization can be viewed as a strategy for controlling an occupation, including solidarity and regulation of the supply of professional workers in the market. It also "provides a basis for the domination of institutions, organizations and other occupations associated with it" (Parry and Parry, 1977, p. 118). This approach recognizes the significance of the underlying structure of power relations in facilitating the process of professionalization and enabling or constraining the formation and development of associations of professionals (Willmott, 1986). Thus, professionalization is the establishment and maintenance of conditions that give rise to the exercise of control by an occupational association to become a profession (Johnson, 1972; 
Larson, 1977; Abbott, 1988; Willmott, 1986). The power of a profession is linked to its relationship with the state, which grants legitimacy to professions (Adams, 2017; Evetts, 2013). The guiding principle of the state-professional relationship is hierarchical control, where laws are put in place to bring professions under state control even though professions appear to act independently.

Threats to professions occur due to changes in the working and social world. Evetts (2013) argues that the globalization of markets jeopardizes the jurisdiction of professions granted by nation-states. Other major forces impacting a profession's status can be classified into four categories: 1) financial-economic pressures (cost-controlling measures and budgets), 2) sociocultural pressures (complexity of clients and public needs from a professional), 3) pressure from public and political turmoil (incidents and insecurity in professional services), and 4) technological pressure (social media and big data influencing professional services) (Noordegraaf, 2020). Furthermore, internal pressures influencing self-regulating professions occur when they put their own interests over those of the public, which prompts legislative changes that threaten professions (Adams, 2017). Overall, financial, socio-cultural, political, technological, globalizing, and internal forces are changing the legitimacy of professions to operate as independent, self-regulating organizations (Evett, 2013; Adams, 2017).

A critique of the literature on threats to professions is that it has largely focused on established professions and does not consider the influences on occupations that are trying to professionalize. This outlines a gap in the literature which this paper addresses. We focus on how some of these forces are influencing the professionalization of financial planning, an occupation attempting to professionalize. Next, the literature on the professionalization of accounting is reviewed, as accounting is a profession operating in the financial services industry.

\subsection{Accounting professionalization}

Literature on the development of the accounting profession does not engage with the professional development of adjacent professions and focuses solely on accounting practices. However, the literature indicates how much the state contributes to professionalization. The state allows for professional power to disseminate and generate within the community and among professionals through market interactions and state interventions. Puxty et al. (1987) argue that three intersecting principles are involved in professionalization: the community as spontaneous solidarity, the market as dispersed competition, and the state as hierarchical 
control. In the professionalization process, the involvement of the state allows for the appearance of a self-regulatory controlling power within the accounting profession, but state involvement persists via bureaucratic or ideological control (Yee, 2009; Veylayutham and Perera, 1996; Mihirat et al., 2020).

A second influence on the accounting profession has been the international financial institutions. Empirical studies depict the influence of the Big 4, 5, or 6 on the accounting profession and show how they supported the agenda of multinational enterprises to deregulate and unpacked opportunities for accounting firms through the creation of standards, practices, identities, and governance (see Boussebaa and Faulconbridge, 2019; Perera et al., 2003; Cooper and Robinson, 2006). Additionally, the Big 4 encourage neo-liberalism as they play a consulting and funding role to global agencies and non-government organizations such as the International Accounting Standard Board. Hopper et al. (2017) have documented how the International Federation of Accountants and the International Accounting Standard Board continue to be obligated to the Big 4 firms. This suggests that the Big 4 firms are power bases, seeking to control the profession to promote their interests, as seen in the move toward nonaudit consultancy services (Boussebaa, 2017; Boussebaa and Faulconbridge, 2019; Donelson et al., 2020). Thus, the Big 4 firms have a significant influence on the professionalization processes.

A third influence on the accounting profession occurs due to scandals and corruption. According to Thornton et al. (2005), the accounting profession has transformed from fiduciary logic focused on increasing the legitimacy of financial statements to corporate logic focused on profit maximization, selling services, and generating profits. This change threatens the accounting profession through a reduced emphasis on fiduciary logic, which is much needed (Thornton et al., 2005). Donelson et al. (2020) found that regulators are cautious as the Big 4 shift their focus outside their auditing practice toward the growing business in consultancy. This shift may detract from the independence of the auditing practice. Consequently, accounting has undergone an increase in state regulation, which "has been driven, to a significant extent, by the historical sequencing of market and corporate scandals" (Thornton et al., 2005, p. 134). Conversely, Toms (2019) argued that the growth of the accounting profession has been an important response in seeking to curtail financial crimes and scandals. Evidence for significant instances of corruption related to individual and coordinated group scandals has spurred reform of regulation for audit practice and the accounting profession (Clikeman, 2013; Carnegie and O'Connell, 2014). Although closer regulatory supervision has 
been established, the measures have not been enough to prevent further scandals. The corporate logics now operating in the accounting profession have suppressed the prime motive for the original professionalization of accounting.

In summary, the accounting profession is challenged by several forces. State interventions ensured the professional legitimacy of accountants, but national influences remain, and accounting professional bodies are not independent of the state. Similarly, Big 4 firms have a large influence on the profession through their self-interest and against a normative backdrop of professional domination and profit motivation. However, this profit orientation puts the accounting profession under pressure to reinforce and maintain its fiduciary logic.

\subsection{Professionalization of financial planning}

The professionalization of financial planning is a topic infrequently researched, yet the limited literature points at institutional involvement as vital in creating a profession. Cull (2009) argues that the professionalization of financial planning will hinge on two factors: 1) cooperation between professional financial planning bodies, financial service providers, and state regulators, and 2) removing product-based remuneration models and replacing them with feefor-service models. However, the product-based remuneration models have remained (Steen et al., 2016), and the accounting professional bodies have not professionalized financial planning, despite ample opportunity to do so (Murphy, 2018). There is a lack of understanding of why this cooperation did not occur and why financial planning did not professionalize.

Other research focuses on whether financial planners themselves are ready to professionalize (Bruce and Ahmed, 2014; Sanders, 2010; Watts and Murphy, 2009). A survey of 78 Australian financial planners found that these financial planners did not adhere to professional standards because they did not agree that financial planning needed a "systematic body of theory" to improve its professional authority (Watts and Murphy, 2009, p. 44). Sanders (2010) finds that while some clients are ready to accept financial planners as a profession, there is a lack of professional readiness among financial planners, the government, and the community. Overall, previous research identifies issues with the professionalization of financial planning but fails to ascertain the institutional logics which have impeded the professionalization of financial planning. Our paper investigates this gap in the research. 


\section{Section 3: Theoretical Framework}

This paper uses the framework of institutional logics to understand the influence of various institutions on the professionalization of financial planning. Institutional logics are defined as "the socially constructed, historical pattern of material practices, assumptions, values, beliefs, and rules by which individuals produce and reproduce their material subsistence, organize time and space, and provide meaning to their social reality" (Thornton and Ocasio, 1999, p. 804). As the institutional logics framework posits that society consists of institutional orders and those institutional logics operate as a frame of reference for these institutional orders (Thornton and Ocasio, 1999; Thornton, 2002), we use this framework to identify the key orders involved with financial planning professionalization and how they use institutional logics as a frame of reference toward financial planning.

Thornton et al. (2012) established an inter-institutional system of seven institutional orders, which are family, religion, state, market, profession, corporation, and the community. Each institutional order has a central logic that constitutes its organizing principles (Richardson and Kilfoyle, 2012). Our research uses this inter-institutional system to outline the three major influences on the professionalization of financial planning, namely the market (for financial advice services), the state (the Australian federal government and associated regulators), and the profession (financial planning professional bodies); each influence has its own institutional logic. Regarding the market, our research focuses on Australian Financial Services (AFS) Licensees, the companies authorizing financial planners and creating the market of financial advice to the public. For the state, we focus on the role of ASIC and FASEA, the key regulators authorized by the Australian government to regulate financial advice. Finally, the profession is the financial planning bodies in Australia, which are the Australian Financial Planning Association (FPA) and Association of Financial Advisers (AFA).

An aspect of research using institutional logics focuses on constructs at a higher level and strives to understand meta-level values, norms, and symbols which make institutions what they are (Johansen and Waldorff, 2017). Researchers are striving to understand contradictory logics that create friction and can facilitate change (Johansen and Waldorff, 2017). Our research ascertains the higher-level logics involved in the professionalization of financial planners. In this sense, we are investigating how the state, the market, and the profession exhibit logics toward financial planning that inhibit professionalization. Our research follows a similar perspective to Thornton et al. (2005), who compared the accounting, architecture, and 
publishing industries to investigate institutional change in these industries. They found that professional logics, market logics, economic scandals, and state regulation had different influences on the professionals in these three industries.

\section{Section 4: Data and Methodology}

Our research method is documentary analysis inspired by Gioia et al. (2013) and follows the pattern-inducing method outlined by Reay and Jones (2016). Gioia et al. (2013) prescribe that research should be driven by a guiding research question. Our initial question was, "What are the issues impeding the professionalization of financial planning in Australia?" Once this research question was established, we sought out previous research and data to address this question. Previous research identified the role institutions take in professionalizing financial planning (Cull, 2009; Murphy, 2018). Thus, this paper took an institutional order perspective, and we conducted an interpretive analysis of major government inquiries into financial advice to answer our research question. The reason for selecting government inquiries is that they represent a collection of information from multiple sources that allows us to identify an institution's approach toward the professionalization of financial planning. The inquiries collect submissions from the wider community to gain opinions on issues arising from and affecting the institutions involved in delivering financial advice.

The next step was to identify those inquiries which were suitable for our research. The authors conducted a review of 63 PJCCFS inquiries written from 1997 to 2014. The data analysis commenced with each author's general reading of these inquiries for relevance, and from that, we selected 16 PJCCFS inquiries. We also added the Wallis Inquiry, the Financial Systems Inquiry, and the Royal Commission for coding analysis. The specific inquiries are outlined in Appendix A.

The authors coded the selected inquires according to very broad constructs (Gioia et al., 2013). Our constructs were: a) regulators, b) the market for financial advice, c) professional bodies, and d) other (these are shown in column 1 of Table 1). Data coding was completed using NVivo software (version 11). The authors immersed themselves in the data, shared the coded data, and met on multiple occasions to discuss their findings and develop interpretations of this data. The constructs were refined to identify a pattern of interrelated themes using thematic analysis (Braun and Clarke, 2006). These themes are outlined in column 2 of Table 1, and we provide the descriptions in column 3 of Table 1 . The refinement of the constructs into themes was 
completed by one author, and discussions were held between all authors to test the validity and appropriateness of each theme. Additionally, the lead author created a map of the relationships between the constructs and themes (Gioia et al., 2013).

[Insert Table 1 around here]

The final step was to relate these constructs and themes to theory. Literature has shown that institutions can be influenced by a single institutional logic (Dai et al., 2017; Thornton et al., 2012). Thus, we derived the prevailing institutional logic of each theme, and each logic is presented in column 4 of Table 1 . Our approach to deriving institutional logics follows a "pattern-inducing" method as outlined by Reay and Jones (2016 p. 449). Using a patterninducing method, we adopted an interpretative approach by immersing ourselves in the data to ascertain and verify the research constructs. Accordingly, our analysis in Section 5 presents rich quotes from our data to convince readers that our interpretations are trustworthy (Reay and Jones, 2016).

\section{Section 5: Findings}

\subsection{Overview of financial planning in Australia}

Financial planning in Australia has emerged as a separate occupation from accounting (Murphy, 2018) and insurance advising (Cull, 2009). The major financial planning body is the FPA, which was formed in 1992 from the merger of two professional bodies, the Association of Independent Professional Advisors and the International Association of Financial Planning (Cowen et al., 2006). The FPA espouses the view that financial planning involves a six-step process (Cull, 2009) and that financial planning advice should be holistic, taking into consideration the client's full financial situation, circumstances, and objectives. The FPA has a code of ethics guiding its members (FPA, 2013) and can award the international professional designation Certified Financial Planner ${ }^{\circledR}\left(\mathrm{CFP}^{\circledR}\right)$ created by the Financial Planning Standards Board (FPSB, 2017). Australia has about 5,523 CFP professionals, the fifth-highest number of any country, behind the USA, Japan, China, and Canada (FPSB, 2020). The AFA is a second professional body, with a code of ethics (AFA, 2018) and its own professional designation, Fellow Chartered Financial Practitioner.

The size of the financial planning industry grew from around 18,000 financial planners in August 2009 to about 25,386 in April 2018 (Commonwealth of Australia, 2018) but tapered to about 23,636 in February 2020 (ASIC, 2020). Approximately four out of five financial planners 
are male, and the industry's culture creates a gender imbalance with impediments for women to enter and succeed as financial planners (Richards et al., 2020, O'Dwyer and Richards, 2021). In 2015-16, the financial planning industry was worth about AUD \$4.6 billion in revenue, and five financial institutions held just under half of this market share (Commonwealth of Australia, 2018). For the financial year 2016-17, it was estimated that revenue in the financial planning industry came from retirement and superannuation advice (33\%), loan and investment advice (25\%), self-managed superannuation funds (20\%), tax advice (10\%), and other activities $(10 \%)$ (Commonwealth of Australia, 2018). Financial planners were remunerated using various methods: fee-for-service, commissions, and bonuses. However, in the Future of Financial Advice (FOFA) reforms implemented in 2013, a ban on conflicted remuneration was introduced, which has curtailed the prevalence of commissions (McInnes, 2020).

The regulatory structure of financial planning centers around ASIC, which controls financial planning using a licensing regime. Entities (and sometimes individuals) apply for an AFS license (McInnes, 2020), and upon becoming an AFS licensee, the organization can authorize financial planners to practice. This regulatory mechanism awards significant power to the AFS licensee over financial planners (Richards and Morton, 2020) but comes with a responsibility to ensure the financial planners' practices are compliant with regulations (McInnes, 2020). With this mechanism, large financial institutions have vertically integrated so they provide both financial products and financial planners who provided advice. This has consolidated the financial advice market, where many financial planners operate under a few AFS licensees.

The expected behavior, requisite knowledge, and vital skills of financial planners are regulated by three institutional orders: the state (ASIC and FASEA), the market (AFS licensees), and the profession (the various professional bodies). The findings are presented for these three main institutional bodies in financial planning by outlining the predominant institutional logic of each as it relates to the professionalization of financial planning.

\subsection{State-ASIC and a logic of self-regulation}

Multiple government bodies have some role in regulating the financial planning industry in Australia, but ASIC has been given the most direct responsibility for regulating financial planning (PJCCFS, 2014) and therefore, the professionalization of financial planning. The question then is why has ASIC not professionalized financial planning? Our research finds that ASIC approached the regulation of the financial planning industry with a logic of selfregulation. 


\subsubsection{Minimalist regulator}

The first finding that supports a self-regulation logic is that when ASIC was created in 1997 (Information and Research Services, 1997), the belief in market efficiency reigned. Thus, when ASIC was formed, it took a minimalist approach to regulation. This is summarized in PJCCFS (2014, p. 7):

The regulation of financial services providers has been designed to maximise market efficiency, with minimal regulatory intervention to protect investors. ASIC informed the committee:

The fundamental policy settings of the FSR [Financial services regulation] regime were developed following the principles set out in the Financial System Inquiry Report 1997 (the Wallis Report). These principles are based on 'efficient markets theory', a belief that markets drive efficiency and that regulatory intervention should be kept to a minimum to allow markets to achieve maximum efficiency. The 'efficient markets theory' has shaped both the FSR regime and ASIC's role and power.

Australia's major financial scandals have occurred while ASIC was regulating financial planning. In response, ASIC normally argues that it has limited power and resources to prevent them (PJCCFS, 2014). However, due to these financial scandals and the global financial crisis, an inquiry realized that the minimalist approach is ongoing and needs to be changed. An inquiry stated (PJCCFS, 2014, p. 25):

The committee is concerned about problems that have occurred in the financial advice industry and the lack of progress in addressing the problems since the committee's previous inquiry in 2009.

\subsubsection{Low education requirements to be a financial planner}

Further evidence of ASIC's logic of self-regulation is the low education requirements it sets to be a financial planner (formally called PS146 and then RG146). ASIC created a low level of competency on the assumption that responsibility to improve competency levels of financial planners above the minimum would be undertaken by industry. However, low requirement levels created a low level of competency in financial planners and inhibited an uplifting of professional standards (The Australian Government the Treasury, 2014). Consider this quote (PJCCFS, 2014, p. 37):

Evidence put to the committee during the inquiry indicates that there is a high degree of concern that RG 146 does not deliver appropriate standards. ... The potential for $R G 146$ requirements to be met through completion of a short training course, possibly only requiring a few hours of study, was a common concern. 
Recent regulatory changes (reviewed in Section 5.4) demonstrate a logic of greater control with an increase in education levels of financial planners, a competency-based examination, and a code of ethics. However, these developments are not under the remit of ASIC but under FASEA, the new body, proof that ASIC was not entrusted with implementing these changes.

\subsubsection{Regulatory mechanism licensing}

There is a need to consider the mechanisms through which the state controls the financial services industry, as this further demonstrates ASIC's logic of self-regulation. The primary mechanism adopted by ASIC is licensing (McInnes, 2020). For financial planners to provide financial advice, they must hold an AFS license or be an authorized representative of a holder of an AFS license. The AFS license as a mechanism of regulating financial planners illustrates ASIC's logic of self-regulation, as it awards control of financial planners to third parties in the financial services industry, most notably to financial product providers or companies aligned with the product providers. However, this mechanism also created conflicts of interest where financial planners have a conflict between working in their clients' interest and working in the financial product providers' interest. PJCCFS (2009b, pp. 69-70) states:

On one hand, clients seek out financial advisers to obtain professional guidance on the investment decisions that will serve their interests, particularly with a view to maximising retirement income. On the other hand, financial advisers act as a critical distribution channel for financial product manufacturers, often through vertically integrated business models or the payment of commissions and other remunerationbased incentives.

This conflict of interest was epitomized in the agriculture managed investment schemes, where financial planners only had one product they could recommend to a client (PJCCFS, 2009a). Conflicts of interest are governed by banning commissions (McInnes, 2020) and through financial planners' disclosure to clients (Richards and Safari, 2021), and there has been little resolve to separate financial product providers from financial advice. One suggestion to resolve the issue of conflict of interest in financial advice has been to license financial planners individually. This has been met by reluctance (PJCCFS 2014, p. 32):

The committee has examined suggestions that each financial adviser be individually licensed rather than licensing organisations. The committee notes that the key objective of this suggestion is to increased individual accountability... The committee is of the view that the dual oversight of an adviser by a professional association (with the power to advise ASIC to suspend or ban the adviser for breaches of the code of professional conduct) and ASIC through the AFS licence provisions will provide accountability for individual conduct. 
Meanwhile, ASIC continues to maintain the current licensing system to regulate financial advice. However, the current system allows conflicts of interest to persist in financial planning because it empowers financial product providers to create financial products and control financial planners simultaneously.

\subsection{Market-AFS licensees and a logic of profit maximization}

The market for financial advice is heavily dominated by AFS licensees who authorize a financial planner to practice and are also either product providers or aligned with product providers to supply financial products to consumers. The most recent inquiry conducted by Hayne (2019) focuses on six licensees, the four major banks (ANZ, NAB, Commonwealth, and Westpac), together with IOOF and AMP, because they authorize $35 \%$ of all financial planners (Commonwealth of Australia, 2018). Our research finds that the way these organizations approach the financial planning industry is guided by the logic of profit maximization.

\subsubsection{Impediments to fiduciary duty}

Evidence of a logic of profit maximization is demonstrated by the inability of financial institutions to incorporate a fiduciary duty into financial planning practices. Most of the major financial institutions in Australia operating in the financial services industry are registered as public corporations with a duty to act in the interests of their shareholders. One duty involves profit maximization so shareholders can obtain a return on their investment. However, this quest for profit maximization can be at odds with the financial planning duty to act in the client's best interest (Richards and Morton, 2020) because financial planners recommend products and strategies based on profit rather than a client's best interest. Hayne (2019, p. 401) states:

...many of the case studies considered in the Commission showed that the financial services entity involved had chosen to give priority to the pursuit of profit over the interests of customers and above compliance with the law.

Additional evidence that large financial institutions have impeded fiduciary duty in financial planning has occurred in the integration of businesses that create financial products with businesses that provide financial advice. This trend, dubbed "vertical integration," was identified in the Murray inquiry as potentially leading to reduced competition in the financial services market (The Australian Government the Treasury, 2014). However, vertical integration has bigger implications for professionalizing financial planning because it conflates 
financial planning with a sales-based activity. Financial planners are authorized to practice and remunerated by the licensees who create financial products and are therefore required to sell those products. This practice removes the independence of judgment required for a financial planning profession to operate where fiduciary duties are required.

\subsubsection{Scandals in financial planning}

Our research also found evidence of financial institutions adopting a logic of profit maximization in the financial scandals that plague the financial services industry. Specific scandals include Storm Financial (PJCCFS, 2009b), Opes Prime (PJCCFS, 2009b), Trio Capital (PJCCFS, 2012), Commonwealth Financial Planning Limited (Hayne, 2018), and the fees-for-no-service scandal (Hayne, 2019). A common thread among these scandals is that financial institutions adopted a logic of profit maximization at the expense of working in the interests of clients. This is summarized by Hayne (2019, p. 138), who states:

I identified several considerations that pointed towards the conclusion that the root cause of the fees for no service conduct was greed: greed by licensees, and greed by (financial) advisers. The evidence that emerged in later rounds of the Commission's hearings only served to reinforce that conclusion.

Overall, these scandals tarnish the reputation of financial planners and inhibit professionalization.

\subsection{Profession - Financial planning professional bodies and a logic of attraction and retention of members}

In this section, we turn to the logic of professional bodies in financial planning. We focus on financial planning professional bodies because accounting professional bodies have not seized the opportunity to bring financial planning into their jurisdiction (Murphy, 2018). Overall, many professional bodies in financial planning share control of financial planning with ASIC, AFS licensees, and now FASEA. Our results show that professional bodies have a logic of member attraction and retention.

\subsubsection{Many bodies and no mandate of membership}

The financial planning professional bodies have a logic focused on attracting and retaining members because many professional bodies are competing in this environment. Hayne (2018, pp. 150-151) states: 
Financial advisers are not currently required to belong to an association, and though some employers of employed financial advisers require it, few if any specify which. Advisers are free to switch between associations at any time, or, as Hagger put it, 'go down the road to another association' if they are expelled. The FPA and AFA therefore actively engage in recruitment of members from the industry and, to some necessary extent, from each other. Membership fees are their chief source of revenue.

We contend that the financial planning professional community is best described as fragmented. There is no government mandate for financial planners to be a member of a professional body, so financial planners can choose whether to join a body and which body to join. As a result, professional bodies have had to fight to retain members, which reduces the bodies' ability to enforce high professional standards for members. This represents a lack of government intervention to empower the financial planning profession via professional bodies. Instead, the government created a new governmental body, FASEA, to improve the professional standards of financial planners.

\subsubsection{Lack of jurisdiction for financial planning}

A second finding which shows that professional bodies adopt a logic of attracting and retaining members is that there is no clear jurisdiction to differentiate financial planning services from other financial services provided by other people. Financial planning emerged from a background of financial product sales (Cull, 2009), so the training requirements to give financial advice (RG 146) emphasize product knowledge and not the skills of tailoring advice to clients. While the Corporations Act 2001 (Cth) S761B distinguishes between personal and general advice, the idea that financial planners are acting as fiduciaries and therefore providing personal financial advice has not been made clear. Importantly, this distinction is not recognized by consumers. There is evidence that the term 'financial planner' has been misused by those who essentially provide general advice (selling financial products) yet pose as giving personal advice. This was found in the PJCCFS inquiry (2014, pp. 35-36):

There was consensus among some submitters that the terms financial planner and financial adviser had been misused to the detriment of consumers...there was concrete evidence of misrepresentation and noted that in the 12 months to 31 December 2012, 'over 12 per cent of ASIC's financial services enforcements related to matters against unlicensed participants'.

This misuse can occur because there is a lack of clarity in the market about what the terms financial adviser and financial planner constitute. This point was found in a survey of the public's perceptions of financial planners as reported to the PJCCFS (2014, p. 24). It found there was no common understanding of the term 'financial planner'. The misuse of the title 
'financial planner' and the lack of clarity regarding whether financial planners provide personal advice inhibit creating a clear jurisdiction for financial planners. However, why have the professional bodies not created and enforced a fiduciary duty-oriented jurisdiction for their members?

The main reason is that financial planning bodies would lose members if they were to enforce a fiduciary duty standard on their members. As mentioned in Section 5.3, financial institutions need to sell products, and the licensing regime empowers financial planners to achieve this. Thus, many financial planners found themselves aligned with financial institutions. ASIC notes in (PJCCFS, 2009b, p. 16) that:

Approximately $85 \%$ of financial advisers are associated with a product manufacturer, so that many advisers effectively act as a product pipeline. Of the remainder, the vast majority receive commissions from product manufacturers and so have incentives to sell products...This structure creates potential conflicts of interest that may be inconsistent with providing quality advice and these conflicts may not be evident to consumers.

With such a high percentage of members and potential members being aligned with product providers, the professional bodies have been unable to create an exclusive fiduciary duty for members because if they do, they risk losing members and excluding potential members.

\subsubsection{Ineffective discipline by professional bodies}

The final evidence that professional bodies adopt an attract and retain members logic is that the discipline systems run by the major professional bodies are ineffective. Hayne $(2018$, p. 150) states:

Both FPA and AFA now have processes and systems for disciplining members. But the evidence before the Commission did not show that either the FPA or the AFA now plays any significant role in maintaining or enforcing proper standards of conduct by financial advisers.

We contend that the ineffective disciplining regime of financial planning professional bodies means that they cannot enforce high standards, and it illustrates that the financial planning professional bodies prioritize a logic of attracting and retaining members. Additionally, the disciplinary system for financial planning is convoluted, with multiple parties being able to discipline financial planners. Discipline can be undertaken by the professional bodies, ASIC, AFS licensees, and the financial ombudsman service (when clients raise external complaints). This system leaves it unclear who is responsible for disciplining certain issues and leads to a system that does not enforce the high standards required to professionalize financial planning. 


\subsection{State - FASEA}

The previous findings investigated how the prevailing institutional logics from the state (ASIC), market (AFS licensees), and the profession (professional bodies) have hindered the professionalization of financial planning. However, the state has introduced a new institution, FASEA, established in 2017 to reform financial planning (FASEA, 2019). The creation of this new regulator testifies to the inability of the state's previous system to progress the change of financial planning from an industry to a profession. While it is too early to ascertain the institutional logic of FASEA, some initiatives warrant appraisal.

Firstly, a focus of FASEA is to reform financial planning by focusing on the individual financial planner, as opposed to the institutional or regulatory system. Evidence for this is that FASEA has been charged with raising the educational standards of new and current financial planners. To become registered, new financial planners require a degree, one year of experience, and must pass a registration examination. Current financial planners will need to pass an examination and retrain to an education level equivalent to a tertiary degree approved by FASEA (2020). Also, FASEA has created, and then had legislated, a code of ethics for financial planners. These initiatives seek to improve the professionalism of financial planners by increasing education levels and making ethics a cornerstone of financial planning practices (Bruhn and Asher, 2021; Richards et al., 2021). However, these changes somewhat marginalize the value of the professional bodies, where maintaining educational levels and a code of ethics would normally reside.

A recommendation not yet undertaken by FASEA is to change the term "general advice" to "product sales information" and "personal advice" to "financial advice" in the Corporations Act 2001 (Cth) to make the distinction easier for the public to understand (PJCCFS, 2014, p. xiii). Further, this inquiry also recommended that legislation protect the title "financial planner" for those who can give financial advice. The Corporations Act 2001 (Cth) S923C now restricts the use of the terms "financial planner" and "financial adviser" to those who provide personal financial advice, but it has not changed the term "general advice" to "product sales information." Finally, FASEA was charged with creating a single disciplinary body for adherence to the FASEA code of conduct, and it has been announced that FASEA will end (The Australian Government the Treasury, 2020), and the Financial Services and Credit Panel (which is a section of ASIC) will take on this regulatory function. At the time of writing, the licensing regime which empowers financial institutions (licensees) to authorize financial 
planners to practice remains in place. However, the Australian financial services landscape has seen significant changes since the Royal Commission, with many of the large financial institutions opting to withdraw from the financial planning industry (Adviser Ratings, 2019). Thus, AFS licensees are no longer dominated by large financial institutions, and a logic different from profit maximization may be instilled.

\section{Section 6: Discussion}

The findings of this study articulate the institutional logics in the financial planning sector as it struggles to professionalize financial planning. We have drawn on inter-institutional theory to show how certain institutional orders, the state (via ASIC and then FASEA), the market (AFS licensees), and the profession (FPA and AFA) have different institutional logics. We also show that these institutional logics differ and impede the professionalization of financial planning.

Research on professionalization argues that power is an essential part of the professionalization process (Adams, 2017; Evetts, 2013) and that the state is highly involved with the creation of professions as it grants legitimacy to professions to create jurisdictions (Puxty et al., 1987; Seal et al., 1996). Where previous research shows that the state seeks its own agenda through controlling the accounting profession (Mihirat et al., 2020), our research shows that in Australian financial planning, the state did not grant legitimacy. A question to ask then is why the state did not intervene to increase the professional standards and legitimacy of financial planners. Our findings show that the state regulator adopted an institutional logic of selfregulation based on free-market efficiency. Thus, a state's involvement in creating professions depends on the logic regulators take toward an occupation. A laissez-faire approach to regulating an occupation will not enable professionalization.

The large financial institutions in the financial advice market used financial planners to sell products by vertically integrating the businesses that create financial products with those that sell financial products. The licensing regime allowed them to do this as it awarded the licensees significant power over the financial planners. This differs from the accounting profession, where the prior literature has found that the large auditing firms played a sizable role in professionalizing accounting (Perera et al., 2003; Cooper and Robinson, 2006). In addition, Toms (2019) argued that the growth of the accounting profession has occurred in order to curtail financial scandals and that there is a relationship between scandals and reform regulation (Clikeman, 2013; Carnegie and O'Connell, 2014). For financial planning, the large financial 
institutions have been at the center of scandals where they have prioritized profit rather than a fiduciary duty for their financial planners (Hayne, 2019). Our research shows that large institutions can impede the professionalization of occupations, especially when the logic of profit-making is at odds with the goals of the profession. In our case, financial institutions have exploited financial planners to achieve their profit-making logic. In the Big 4 accounting firms, the goal of the firm to provide accountancy services is aligned with the accounting profession. Nonetheless, the big firms are now focusing heavily on non-audit consultancy services rather than on auditing practice (Donelson et al., 2020), and this could cause problems for the accounting profession.

Numerous scandals have occurred in the accounting profession (Carnegie and O'Connell, 2014; Toms, 2019), yet the accounting bodies are well-established professional organizations with exceptionally strong power bases. Thus, they are able to protect their jurisdiction and explicitly work for their self-interest. Financial planning as an emerging profession is more vulnerable to turbulence, corruption, and scandal. Therefore, the rising number of scandals led to further regulation and intervention by the state with the creation of FASEA in 2017. The introduction of a new body to create these standards reinforces the view that the state does not believe the financial planning professional bodies can professionalize financial planners. In the accounting profession, the literature shows that its professional body has been active in creating jurisdictions, increasing standards, and disciplining members (Clikeman, 2013). This shows a clear difference between accountants and financial planners. Our contribution to theory is identifying that the financial planning professional bodies have a logic of member attraction and retention due to financial planners being able to change professional bodies easily or simply not being a member of one. This has constrained the ability of the professional bodies to align financial planning with a fiduciary duty and enforce professionalization.

\section{Section 7: Conclusion}

This paper has investigated the professionalization of financial planning in Australia, where the movement from a sales-based industry to a profession is incomplete. The paper shows how institutional logics of the state, market, and profession can impede the professionalization process; thus, it has implications for policymakers and practitioners in financial planning. Our research shows that if regulators adopt a logic of self-regulation by the industry, it will not lead to an increase in professional standards. Regulators need to be more involved with creating a profession, and an apt approach is to do this in conjunction with professional bodies. A large 
impediment to professional bodies creating a financial planning profession is that they must fight for members. In this situation, they are unable to enforce ethics and professional standards on members. The state and the profession need to collaborate so a jurisdiction for financial planning can be created and professional and ethical standards can be lifted. Large financial institutions need to review whether a profit-making logic is appropriate when providing financial advice. A growing amount of research shows that financial planning is an ethicsbased practice (Bruhn and Asher, 2021; Richards et al., 2021). A profit-making logic that rewards financial planners' selling abilities through commissions is at odds with an ethical approach and can lead to serious implications for consumers, government, and the financial institutions themselves (Steen et al., 2016). More debate is needed about how to reconcile the profit-making aspect of financial advice with the client's best interest (Richards and Morton, 2020).

There are several limitations to be recognized in these findings. This study was conducted in an Australian context. The results of this study are not readily generalizable to other developed countries, as financial advice there may have different settings and implications. Future research in Australia and elsewhere could focus on using interviews with key stakeholders to discover their views on financial advice and the financial planning profession. However, it would not be unreasonable to suggest that what is becoming evident in Australia might be a precursor to what will happen everywhere else.

\section{References:}

Abbott, A. D. (1988), The system of professions: an essay on the division of expert labor, University of Chicago Press, Chicago.

Adams, T. L. (2017), "Self-regulating professions: Past, present, future". Journal of Professions and Organization, Vol. 4 No. 3, pp. 70-87. https://doi.org/10.1093/jpo/jow004

Adviser Ratings (2019), Adviser musical chairs report: industry research on financial adviser movement. https://cdn2.hubspot.net/hubfs/5373226/Musical-Chairs-2019-Q4.pdf

AFA (2018), AFA Code of Conduct. Available at: https://www.afa.asn.au/afa-code-conduct (Accessed 1 May 2018).

ASIC (2020), Financial Advisers Dataset. Available at: https://www.data.gov.au/dataset/dsdga-f2b7c2c1-f4ef-4ae9-aba5-45c19e4d3038/details (Accessed 15 Feb 2020).

Ballas, A. A. (1998), "The creation of the auditing profession in Greece". Accounting, Organizations and Society, Vol. 23, pp. 715-736.

Boussebaa, M. (2017), "Global professional service firms, transnational organizing and core/periphery networks" in Seabrooke, L, and Henriken, L.F. (eds) Professional Networks in Transnational Governance, 233-244 Cambridge University Press, Cambridge. 
Boussebaa, M., and Faulconbridge, J. R. (2019), "Professional service firms as agents of economic globalization: a political perspective". Journal of Professions and Organization, Vol.6 No.1, pp. 72-90. https://doi.org/10.1093/jpo/joy014

Braun, V., and Clarke, V. (2006), "Using thematic analysis in psychology". Qualitative Research in Psychology, Vol. 3 No 2, 77-101.

Bruce, Ken., and Abdullahi Dahir. Ahmed. (2014) Conceptions of Professionalism: Meaningful Standards in Financial Planning. Gower Publishing, Farnham, UK.

Bruhn, A. and Asher, A. (2021), The primacy of ethics in the provision of financial advice. Accounting \& Finance, 61: 3305-3327. https://doi.org/10.1111/acfi.12703

Caramanis, C.V. (2002), "The interplay between professional groups, the state and supranational agents: Pax Americana in the age of 'globalisation'". Accounting, Organizations and Society, Vol. 27, pp. 379-408.

Carnegie, G.D. and O'Connell, B.T., (2014), "A longitudinal study of the interplay of corporate collapse, accounting failure and governance change in Australia: early 1890s to early 2000s". Critical Perspectives on Accounting, Vol. 25, No.6, pp. 446-468. https://doi.org/10.1016/j.cpa.2013.04.001

Chua, W. F. and Poullaos, C. (1993), "Rethinking the profession-state dynamic: the case of the Victorian charter attempt, 1885-1906". Accounting, Organizations and Society, Vol.18, pp. 691-728.

Clikeman, P.M., (2013), Called to Account: Financial Frauds That Shaped the Accounting Profession. Routledge, New York.

Commonwealth of Australia (2018), Some Features of the Australian Financial Planning Industry Background Paper 6 (Part A). Available at: https://financialservices.royalcommission.gov.au/publications/Documents/features-ofthe-australian-financial-planning-industry-paper-6.pdf. (Accessed 10 Jan 2019).

Cooper, D. J., and Robson, K. (2006), "Accounting, professions and regulation: locating the sites of professionalization". Accounting, Organizations and Society, Vol. 31 Nos. 4-5; pp. 415-444. https://doi.org/10.1016/j.aos.2006.03.003

Corporations Act Chapter 7 Act no. 50 (2001).

Cowen, J. E., Blair, W. T. and Taylor, S. M. (2006), "Personal financial planning education in Australian universities". Financial Services Review, Vol. 15, pp. 43-57.

Cull, M. (2009), "The rise of the financial planning industry". Australasian Accounting Business \& Finance Journal, Vol.3, 26-37.

Dai, N. T., Tan, Z. S., and Tang, G. (2017), "IPOs, institutional complexity, and management accounting in hybrid organisations: a field study in a state-owned enterprise in China". Management Accounting Research, Vol .36, pp. 2-23. https://doi.org/10.1016/j.mar.2016.07.006

Dimaggio, P. and Powell, W. (1983), "The iron cage revisited: institutional isomorphism and collective rationality in organizational fields". American Sociological Review, Vol. 48 pp. 147-160. https://doi.org/10.2307/2095101

Donelson, D. C., Ege, M., Imdieke, A. J., and Maksymov, E. (2020), "The revival of large consulting practices at the Big 4 and audit quality". Accounting, Organizations and Society, Vol. 87, 101157. https://doi.org/10.1016/j.aos.2020.101157

Edwards, J. R., Anderson, M. and Chandler, R. A. (2007), "Claiming a jurisdiction for the "Public Accountant" in England prior to organisational fusion". Accounting, Organizations and Society, Vol. 32, pp. 61-100.

Evetts, J. (2013), Professionalism: value and ideology. Current Sociology, Vol. 61 Nos. 5-6, 778-796. https://doi.org/10.1177/0011392113479316 (Accessed 14 Feb. 2020).

FASEA (2019), About Us. Available at: https://www.fasea.gov.au/about/. (Accessed $10 \mathrm{Feb}$ 2020). 
FASEA (2020), FASEA's Standards - An integrated framework. Available at: https://www.fasea.gov.au/standards/ (Accessed 15 Feb 2020).

FPA (2013), "The pillars of our profession: code of professional practice". (Accessed 10 Feb 2020).

FPSB (2017), Organizations Offering CFP Certification. Available at: https://www.fpsb.org/about-financial-planning/find-a-planner/. (Accessed $28 \mathrm{Feb}$ 2017).

FPSB (2020), Financial Planning Standards Board Reports Record Number of CERTIFIED FINANCIAL PLANNER Professionals Worldwide. Available at: https://www.fpsb.org/news/financial-planning-standards-board-reports-recordnumber-of-certified-financial-planner-professionals-worldwide/ (Accessed 29 Feb 2020).

Friedland, R. and Alford, R. (1991), "Bringing society back in: symbols, practices, and institutional contradictions". In: Powell, W.W. and DiMaggio, P. J. (eds) The New Institutionalism in Organizational Analysis. The University of Chicago Press, Chicago pp. 232-263.

Gioia, D. A., Corley, K. G., and Hamilton, A. L. (2013), "Seeking qualitative rigor in inductive research: notes on the Gioia methodology". Organizational Research Methods, Vol. 16 No.1, 15-31. https://doi.org/10.1177/1094428112452151

Greenwood, R, Raynard, M., and Kodeih, F. (2011), "Institutional complexity and organizational responses". The Academy of Management Annals, Vol. 5, pp. 317-371. https://doi.org/10.5465/19416520.2011.590299

Hayne, K. (2018), Interim Report Royal Commission into Misconduct in the Banking, Superannuation and Financial Services Industry. Commonwealth of Australia.

Hayne, K. (2019), Final Report Royal Commission into Misconduct in the Banking, Superannuation and Financial Services Industry Volume 1. Commonwealth of Australia.

Hopper, T., Lassou, P., and Soobaroyen, T. (2017), "Globalisation, accounting and developing countries". Critical Perspectives on Accounting, Vol. 43, pp. 125-148. https://doi.org/10.1016/j.cpa.2016.06.003

Information and Research Services. (1997), The Wallis Report on the Australian Financial System: Summary and Critique. Report for Parliament of Australia. Canberra: Department of Parliamentary Library.

Johansen, C. B., and Waldorff, S. B. (2017), What are institutional logics-and where is the perspective taking us?. In New Themes in Institutional Analysis Topics and Issues from European Research. Krücken, G., Mazza, C., Meyer, R. E. and Walgenbach. P. (eds) Edward Elgar Publishing, Cheltenham UK.

Johnson, T. J. (1972), Professions and Power, The MacMillan Press Ltd, London.

Larson, M. S. (1977), The Rise of Professionalism: A Sociological Analysis, University of California Press, Berkeley.

McInnes, A. (2020), The Regulation of Financial Planning in Australia: Current practice, issues and empirical analysis Routledge, Abingdon, UK.

Mihret, D. G., Mirshekary, S., and Yaftian, A. (2020), "Accounting professionalisation, the state, and transnational capitalism: the case of Iran". Accounting, Organisations and Society, Vol. 82, 101091. https://doi.org/10.1016/j.aos.2019.101091

Murphy, B. (2018), Financial Planning and Accounting in Australia: A Contest for Jurisdiction 1980- 2014. PhD Thesis. University of Wollongong.

Noordegraaf, M. (2020), "Protective or connective professionalism? How connected professionals can (still) act as autonomous and authoritative experts". Journal of 
Professions and Organization, Vol. 7 No. 2, pp. 205-223. https://doi.org/10.1093/jpo/joaa011

O'Dwyer, M., \& Richards, D. W. (2021). Occupational boundaries: Gender capital and career progression in the financial planning industry. Financial Planning Review, e1123. https://doi.org/10.1002/cfp2.1123

Parry, N. and Parry, J. (1977), "Social closure and collective social mobility", in Scase, R. (Ed.), Industrial Society Class, Cleavage and Control, George Allen and Unwin, London.

Perera, H., Rahman, A. and Cahan, S. (2003), "Globalization and major accounting firms". Australian Accounting Review, Vol. 13, pp. 27-37. https://doi.org/10.1111/j.18352561.2003.tb00217.x

PJCCFS (2009a), Inquiry into aspects of agribusiness managed investment schemes. Report for Parliament of Australia. Canberra: Senate Printing Unit, Parliament House. https://www.aph.gov.au/Parliamentary_Business/Committees/Joint/Corporations_and Financial_Services/Completed_inquiries/2008-10/MIS/index (Accessed $10 \mathrm{Feb}$ 2020).

PJCCFS (2009b), Inquiry into financial products and services in Australia. Report for Parliament of Australia. Canberra: Senate Printing Unit, Parliament House. https://www.aph.gov.au/Parliamentary_Business/Committees/Joint/Corporations_and Financial_Services/Completed_inquiries/2008-10/fps/index (Accessed 10 Feb 2020).

PJCCFS (2012), Inquiry into the collapse of Trio Capital. Report for Parliament of Australia. Canberra: Senate Printing Unit, Parliament House. https://www.aph.gov.au/Parliamentary_Business/Committees/Joint/Corporations_and Financial_Services/Completed_inquiries/2010-13/trio/index (Accessed 4 Feb 2020).

PJCCFS (2014), Inquiry into proposals to lift the professional, ethical and education standards in the financial services industry. Report for Parliament of Australia. Canberra: Senate Printing Unit, Parliament House. https://www.aph.gov.au/Parliamentary_Business/Committees/Joint/Corporations_and Financial Services/Financial Adviser_Qualifications (Accessed 3 March 2020).

Puxty, A. G., Willmott, H. C., Cooper, D. J., and Lowe, T. (1987), "Modes of regulation in advanced capitalism: locating accountancy in four countries". Accounting, Organizations and Society, Vol. 12 No.3, pp.273-291.

Reay, T., \& Jones, C. (2016). Qualitatively capturing institutional logics. Strategic Organization, Vol 14. No. 4, pp. 441-454. https://doi.org/10.1177/1476127015589981

Richards D. W., Ahmed A.D., Bruce K. (2021) "Ethics in financial planning: analysis of ombudsman decisions using codes of ethics and fiduciary duty standards". Australian Journal of Management. June https://doi.org/10.1177/03128962211022568

Richards, D. W. and Morton, E. (2020), "Conceptualising financial advice in Australia: the impact of business models and external stakeholders on client's best interest practice”. Financial Services Review Vol. 28 No. 2, pp. 133-158.

Richards, D. W., Roberts, H. and Whiting, R. H. (2020), "Female financial advisers: where art thou?" Australian Journal of Management. Vol. 45 No. 4, pp. 624-644 https://doi.org/10.1177/0312896219896389

Richards, D. W. and Safari, M. (2021), "Disclosure effectiveness in the financial planning industry". Qualitative Research in Financial Markets, Vol. ahead-of-print No. aheadof-print. https://doi.org/10.1108/QRFM-04-2020-0060

Richardson, A. J. and Kilfoyle, E. (2012), "Merging the profession: a historical perspective on accounting association mergers in Canada". Accounting Perspectives Vol.11, pp.77109. 
Sanders, D. (2010), Professional enlightenment of financial planning in Australia. Professional Doctorate. CQ University.

Seal, W., Sucher, P., and Zelenka, I. (1996), "Post-Socialist transition and the development of an accountancy profession in the Czech Republic". Critical Perspectives on Accounting, 7, pp. 485-508.

Steen, A, McGrath D. and Wong A. (2016), "Market failure, regulation and education of financial advisors". Australasian Accounting Business \& Finance Journal, Vol. 10, No. 1 pp. 3-17. http://dx.doi.org/10.14453/aabfj.v10i1.2

The Australian Government the Treasury (2014), Financial Systems Inquiry Report for Government of Australia. Langton Crescent Parkes ACT: Treasury. https://treasury.gov.au/sites/default/files/2019-03/p2014-FSI-01Final-Report.pdf (Accessed 3 March 2020).

The Australian Government the Treasury (2020) Strengthening and streamlining oversight of the financial advice sector Retrieved from https://ministers.treasury.gov.au/ministers/jane-hume-2019/mediareleases/strengthening-and-streamlining-oversight-financial-advice (Accessed on the 02 March 2021).

Thornton, P. H. (2002), "The rise of the corporation in a craft industry: conflict and conformity in institutional logics". Academy of Management Journal, Vol. 45, No.1 pp. 81-101. https://doi.org/10.2307/3069286

Thornton, P. H., and Ocasio, W. (1999), "Institutional logics and the historical contingency of power in organizations: executive succession in the higher education publishing industry, 1958-1990". American Journal of Sociology, Vol. 105, No.3, pp: 801-843. https://doi.org/10.1086/210361

Thornton, P. H., Jones, C. and Kury, K. (2005), "Institutional Logics and Institutional Change in Organizations: Transformation in Accounting, Architecture, and Publishing", Jones, C. and Thornton, P. H. (Ed.) Transformation in Cultural Industries (Research in the Sociology of Organizations, Vol. 23), Emerald Group Publishing Limited, Bingley, pp. 125-170. https://doi.org/10.1016/S0733-558X(05)23004-5

Thornton, P. H., Ocasio, W. and Lounsbury, M. (2012), The institutional logics perspective foundations, research, and theoretical elaboration, Oxford University Press, Oxford.

Toms, S. (2019), "Financial scandals: a historical overview". Accounting and Business Research, Vol.49 No.5, pp. 477-499, https://doi.org/10.1080/00014788.2019.1610591

Veylayutham, S. and Perera, H. (1996), "Recent developments in the accounting profession in New Zealand: A case of professionalization?” The International Journal of Accounting, Vol.31, pp. 445-462.

Watts, T. and Murphy, B. (2009), "Assessing professionalism: the case of financial planning". The Finsia Journal of Applied Finance (JASSA), No. 2, pp. 40-44.

Willmott, H. C. (1986), "Organising the profession: a theoretical and historical examination of the development of the major accountancy bodies in the UK". Accounting, Organizations and Society, Vol. 11 No. 4, pp. 555-80.

Yapa, P. W. S., Jacobs, K. and Huot, B. C. (2016), "The field of accounting: exploring the presence and absence of accounting in Cambodia". Accounting, Auditing \& Accountability Journal, Vol. 29, pp. 401-427. https://doi.org/10.1108/AAAJ-02-2012$\underline{00942}$

Yee, H. (2009), "The re-emergence of the public accounting profession in China: A hegemonic analysis". Critical Perspectives on Accounting, Vol. 20 No. 1, pp. 71-92. https://doi.org/10.1016/j.cpa.2007.03.008 
Table 1: Constructs and themes from coding of data

\begin{tabular}{|c|c|c|c|}
\hline $\begin{array}{l}\text { Main Constructs } \\
\text { (institutional order) }\end{array}$ & Theme & Description & Logic \\
\hline \multirow[t]{3}{*}{ A. Regulators (state) } & $\begin{array}{l}\text { A.1. Minimalist } \\
\text { regulator }\end{array}$ & $\begin{array}{l}\text { Issues with self-regulation and } \\
\text { general state involvement in } \\
\text { financial planning }\end{array}$ & \multirow[t]{3}{*}{$\begin{array}{l}\text { Self- } \\
\text { regulation }\end{array}$} \\
\hline & $\begin{array}{l}\text { A.2. Regulatory } \\
\text { mechanism and changes } \\
\text { in institutional } \\
\text { structures }\end{array}$ & $\begin{array}{l}\text { The licensing mechanism and } \\
\text { other mechanisms controlling } \\
\text { financial planning }\end{array}$ & \\
\hline & $\begin{array}{l}\text { A.3. Education and } \\
\text { competency levels }\end{array}$ & $\begin{array}{l}\text { Financial planners' low education } \\
\text { and competence }\end{array}$ & \\
\hline \multirow[t]{2}{*}{$\begin{array}{l}\text { B. } \text { Market for } \\
\text { professional } \\
\text { financial advice } \\
\text { (market) }\end{array}$} & $\begin{array}{l}\text { B.1. Ethical issues of } \\
\text { fiduciary duty }\end{array}$ & $\begin{array}{l}\text { Identifies issues impeding } \\
\text { financial planners from fiduciary } \\
\text { duty or providing advice in a } \\
\text { client's best interest }\end{array}$ & \multirow[t]{2}{*}{$\begin{array}{l}\text { Profit } \\
\text { maximization }\end{array}$} \\
\hline & $\begin{array}{l}\text { B.2. Damage from } \\
\text { scandals }\end{array}$ & $\begin{array}{l}\text { Reputation damages due to } \\
\text { financial scandals }\end{array}$ & \\
\hline \multirow[t]{4}{*}{$\begin{array}{l}\text { C. Professional } \\
\text { bodies } \\
\text { (profession) }\end{array}$} & $\begin{array}{l}\text { C.1. No mandate and } \\
\text { many professional } \\
\text { bodies }\end{array}$ & $\begin{array}{l}\text { Professional bodies challenges } \\
\text { and competition for members }\end{array}$ & \multirow[t]{4}{*}{$\begin{array}{l}\text { Attract and } \\
\text { retain } \\
\text { members }\end{array}$} \\
\hline & $\begin{array}{l}\text { C.2. Conflict between } \\
\text { professional bodies and } \\
\text { product providers }\end{array}$ & $\begin{array}{l}\text { Conflict between professional } \\
\text { body members and financial } \\
\text { institutions }\end{array}$ & \\
\hline & $\begin{array}{l}\text { C.3. Definition of } \\
\text { financial advice }\end{array}$ & $\begin{array}{l}\text { Jurisdiction of financial planning } \\
\text { and distinction between general } \\
\text { and personal advice }\end{array}$ & \\
\hline & $\begin{array}{l}\text { C.4 Discipline of } \\
\text { financial planners }\end{array}$ & $\begin{array}{l}\text { Discipline of financial planners by } \\
\text { professional bodies }\end{array}$ & \\
\hline D. Other & $\begin{array}{l}\text { D. Other relevant } \\
\text { evidence that does not } \\
\text { apply to the above }\end{array}$ & $\begin{array}{l}\text { All other related that needs to be } \\
\text { taken into account }\end{array}$ & $\mathrm{N} / \mathrm{A}$ \\
\hline
\end{tabular}


Appendix A: Inquiries Reviewed

\begin{tabular}{|c|c|c|c|c|}
\hline $\begin{array}{l}\text { Report } \\
\text { Number }\end{array}$ & Year & $\begin{array}{l}\text { Written } \\
\text { Submissions }\end{array}$ & Pages & PJCCFS Report Name \\
\hline \multicolumn{5}{|c|}{ PJCCFS Reports } \\
\hline 1 & (2014) & 39 & 103 & $\begin{array}{l}\text { Inquiry into proposals to lift the professional, ethical and } \\
\text { education standards in the financial services industry }-2014\end{array}$ \\
\hline 2 & (2013b) & 13 & 66 & $\begin{array}{l}\text { Regulatory framework for tax (financial) advice services } \\
\text { (previously Tax Laws Amendment (2013 Measures No. 2) } \\
\text { Bill 2013, Schedules } 3 \text { and 4) }\end{array}$ \\
\hline 3 & (2013a) & 15 & 76 & $\begin{array}{l}\text { Corporations Amendment (Simple Corporate Bonds and } \\
\text { Other Measures) Bill }\end{array}$ \\
\hline 4 & $(2012 b)$ & 77 & 204 & Inquiry into the collapse of Trio Capital -2012 \\
\hline 5 & (2012a) & 69 & 220 & $\begin{array}{l}\text { Corporations Amendment (Future of Financial Advice) Bill } \\
2011 \text { and Corporations Amendment (Further Future of } \\
\text { Financial Advice Measures) Bill } 2011\end{array}$ \\
\hline 6 & $(2009 \mathrm{~b})$ & 407 & 209 & Inquiry into financial products and services in Australia \\
\hline 7 & $(2009 a)$ & 60 & 95 & $\begin{array}{l}\text { Inquiry into aspects of agribusiness managed investment } \\
\text { schemes }\end{array}$ \\
\hline 8 & (2007b) & 96 & 266 & The structure and operation of the superannuation industry \\
\hline 9 & $(2007 a)$ & 14 & 40 & $\begin{array}{l}\text { Corporations Legislation Amendment (Simpler Regulatory } \\
\text { System) Bill } 2007 \text { and related bills }-2007\end{array}$ \\
\hline 10 & $(2005)$ & 26 & 64 & Property Investment Advice - Safe as Houses? \\
\hline 11 & (2004a) & 31 & 61 & $\begin{array}{l}\text { Corporations Amendment Regulations 7.1.29A, 7.1.35A and } \\
7.1 .40(\mathrm{~h})-2004\end{array}$ \\
\hline 12 & $(2004 b)$ & 23 & 101 & $\begin{array}{l}\text { Corporations Amendment Regulations 2003 (Batch 6); } \\
\text { Corporations Amendment Regulations 2003/04 (Batch 7); } \\
\text { and Draft Regulations - Corporations Amendment } \\
\text { Regulations }\end{array}$ \\
\hline 13 & $(2003)$ & 49 & 86 & Inquiry into the disclosure of commissions on risk products \\
\hline 14 & $(2002)$ & 40 & 108 & $\begin{array}{l}\text { Report on the Regulations and ASIC Policy Statements made } \\
\text { under The Financial Services Reform Act } 2001\end{array}$ \\
\hline 15 & (2001) & 113 & 132 & Report on the financial services reform bill 2001 \\
\hline 16 & $(2000)$ & 63 & 48 & Report on the Draft Financial Services Reform Bill \\
\hline \multicolumn{5}{|c|}{ Other Inquiries } \\
\hline 17 & (2019) & 10,323 & 530 & $\begin{array}{l}\text { The Royal Commission into Misconduct in the Banking, } \\
\text { Superannuation and Financial Services Industry- Final } \\
\text { Report }\end{array}$ \\
\hline 18 & $(2018)$ & 10,323 & 375 & $\begin{array}{l}\text { The Royal Commission into Misconduct in the Banking, } \\
\text { Superannuation and Financial Services Industry- Interim } \\
\text { Report }\end{array}$ \\
\hline 19 & (2014) & 6,780 & 320 & Financial Systems Inquiry (Murray Inquiry) \\
\hline 20 & (1997) & 0 & 40 & $\begin{array}{l}\text { The Wallis Report on the Australian Financial System: } \\
\text { Summary and Critique }\end{array}$ \\
\hline
\end{tabular}




\section{References}

Hayne K. (2018). Interim Report Royal Commission into Misconduct in the Banking, Superannuation and Financial Services Industry. Commonwealth of Australia

Hayne K. (2019). Final Report Royal Commission into Misconduct in the Banking, Superannuation and Financial Services Industry Volume 1. Commonwealth of Australia

Information and Research Services (1997). The Wallis Report on the Australian Financial System: Summary and Critique. Report for Parliament of Australia. Canberra: Department of Parliamentary Library.

PJCCFS (2002). Report on the Regulations and ASIC Policy Statements made under The Financial Services Reform Act 2001. Report for Parliament of Australia. Canberra: Senate Printing Unit, Parliament House.

PJCCFS (2003). Inquiry into the disclosure of commissions on risk products. Report for Parliament of Australia. Canberra: Senate Printing Unit, Parliament House.

PJCCFS (2004a). Corporations Amendment Regulations 7.1.29A, 7.1.35A and 7.1.40(h) 2004. Report for Parliament of Australia. Canberra: Senate Printing Unit, Parliament House.

PJCCFS (2004b). Corporations Amendment Regulations 2003 (Batch 6); Corporations Amendment Regulations 2003/04 (Batch 7); and Draft Regulations-Corporations Amendment Regulations 2004 (Batch 8). Report for Parliament of Australia. Canberra: Senate Printing Unit, Parliament House.

PJCCFS (2005). Property Investment Advice - Safe as Houses? Report for Parliament of Australia. Canberra: Senate Printing Unit, Parliament House.

PJCCFS (2007a). Corporations Legislation Amendment (Simpler Regulatory System) Bill 2007 and related bills. Report for Parliament of Australia. Canberra: Senate Printing Unit, Parliament House.

PJCCFS (2007b). The structure and operation of the superannuation industry. Report for Parliament of Australia. Canberra: Senate Printing Unit, Parliament House.

PJCCFS (2009a). Inquiry into aspects of agribusiness managed investment schemes. Report for Parliament of Australia. Canberra: Senate Printing Unit, Parliament House.

PJCCFS (2009b). Inquiry into financial products and services in Australia. Report for Parliament of Australia. Canberra: Senate Printing Unit, Parliament House.

PJCCFS (2012a). Corporations Amendment (Future of Financial Advice) Bill 2011 and Corporations Amendment (Further Future of Financial Advice Measures) Bill 2011. Report for Parliament of Australia. Canberra: Senate Printing Unit, Parliament House.

PJCCFS (2012b). Inquiry into the collapse of Trio Capital. Report for Parliament of Australia. Canberra: Senate Printing Unit, Parliament House.

PJCCFS (2013a). Corporations Amendment (Simple Corporate Bonds and Other Measures) Bill 2013. Report for Parliament of Australia. Canberra: Senate Printing Unit, Parliament House.

PJCCFS (2013b). Regulatory framework for tax (financial) advice services (previously Tax Laws Amendment (2013 Measures No. 2) Bill 2013, Schedules 3 and 4). Report for Parliament of Australia. Canberra: Senate Printing Unit, Parliament House.

PJCCFS (2014). Inquiry into proposals to lift the professional, ethical and education standards in the financial services industry. Report for Parliament of Australia. Canberra: Senate Printing Unit, Parliament House. 
PJSCCS (2000). Report on the Draft Financial Services Reform Bill. Report for Parliament of Australia. Canberra: Senate Printing Unit, Parliament House.

PJSCCS (2001). Report on the Financial Services Reform Bill 2001. Report for Parliament of Australia. Canberra: Senate Printing Unit, Parliament House.

The Australian Government the Treasury (2014). Financial Systems Inquiry Report for Government of Australia. Langton Crescent Parkes ACT: Treasury. 